\title{
The Use of IT Solutions Offered in the Public Cloud to Reduce the City's Carbon Footprint
}

\author{
Tomasz Turek $^{1, *\left(\mathbb{D}, \text { Damian Dziembek }^{1} \text { and Marcin Hernes }\right.}{ }^{2}(\mathbb{D})$ \\ 1 Faculty of Management, Czestochowa University of Technology, Armii Krajowej 19B, \\ 42-201 Częstochowa, Poland; damian.dziembek@pcz.pl \\ 2 Faculty of Management, Wroclaw University of Economics and Business, Komandorska 118/120, \\ 53-345 Wrocław, Poland; marcin.hernes@ue.wroc.pl \\ * Correspondence: tomasz.turek@pcz.pl; Tel.: +48-34-32-50-391
}

check for updates

Citation: Turek, T.; Dziembek, D.; Hernes, M. The Use of IT Solutions Offered in the Public Cloud to Reduce the City's Carbon Footprint. Energies 2021, 14, 6389. https://doi.org/ 10.3390/en14196389

Academic Editors: Dorota Jelonek and Andrzej Sobczak

Received: 31 July 2021

Accepted: 29 September 2021

Published: 6 October 2021

Publisher's Note: MDPI stays neutral with regard to jurisdictional claims in published maps and institutional affiliations.

Copyright: (c) 2021 by the authors. Licensee MDPI, Basel, Switzerland. This article is an open access article distributed under the terms and conditions of the Creative Commons Attribution (CC BY) license (https:/ / creativecommons.org/licenses/by/ $4.0 /)$.

\begin{abstract}
An important trend in today's economy is to reduce the carbon footprint of organizations, businesses and households. Modern technologies, including ICT solutions, contribute to the reduction of $\mathrm{CO}_{2}$ production. The article focuses on the potential of using the cloud computing model in managing a modern and intelligent city. Modern city offices have an extensive IT infrastructure. With the emergence of new services provided online by the offices, the server infrastructure is also developing. Server rooms together with additional devices are characterized by high demand for electricity. Along with this, significant amounts of $\mathrm{CO}_{2}$ are produced. An alternative is the use of Cloud Computing solutions, which contribute to a significant reduction of the carbon footprint. The paper analyses potential solutions that can be used in city offices. The benefits and positive impact on the environment were highlighted. The empirical research was conducted based on questionnaires received from city offices. The results obtained indicate that city halls contribute significantly to the production of $\mathrm{CO}_{2}$. Moving IT services and solutions in whole or in part to cloud computing should be considered as one of the important elements of managing a smart and green city.
\end{abstract}

Keywords: smart city; cloud computing; carbon footprint (CF)

\section{Introduction}

The dynamic development of information technology results in the emergence of new opportunities in the field of acquiring and using IT solutions by various types of organizations, including specific units such as cities and municipalities. Cloud computing is currently a particularly important and increasingly popular model for the acquisition and use of IT solutions in organizations. IT tools and services offered by providers in cloud computing (e.g., in the field of ICT infrastructure, programming platform, software) are characterized by high functionality, technological advancement and financial efficiency [1]. As a result, many organizations (both business and non-business), instead of developing their own IT infrastructure, more and more often decide to use IT services available in cloud computing. Cloud computing is transforming the IT market and redefining the way vendors offer and develop IT tools and services [2]. Moreover, cloud computing introduces an evolution in terms of the current rules of using and paying for IT solutions by organizations. Increasing the scale of applications of Cloud Computing solutions may affect not only the improvement of the effectiveness of individual organizations, but also may affect the development of the entire economy of individual countries (including countries grouped in the European Union).

Each city is responsible for the implementation of specific strategic goals (with a wide time horizon) and operational (current) goals. These goals include the development of infrastructure, management of spatial order, servicing residents, attracting investors and investments, and using the natural potential to build multi-layer business and social 
relations. In fact, each of these activities in the era of electronic economy and information society requires the involvement of IT solutions. Residents deal with more and more cases electronically. Investors are looking for attractive locations for their business on dedicated portals. This has a significant impact on the development of the IT infrastructure of each city hall and units associated with it $[3,4]$.

From the point of view of environmental protection, a particularly important issue is the impact of cloud computing on the carbon footprint of an organization. It is assumed that the use of technologies such as cloud computing, artificial intelligence, machine learning, the Internet of Things can reduce energy consumption and greenhouse gas emissions, thus contributing to the protection of the natural environment. It is especially important in regard to smart cities.

Many research works, for instance [5-8], are devoted mainly to using a new IT technologies in smart cities or to analysis the influence the utilization of cloud computing on reduction of carbon footprints [5,9-11]. There are also many publication related to energy management in mobile devices and applications [6-8]. However, there is the research gap related to utilization the cloud computing for carbon footprint reducing in smart cities.

The aim of the paper is to analyze and compare energy consumption for the traditional way of maintaining IT infrastructure (on-premise model) and in relation to the cloud computing model for a selected group of cities in Poland in the context of carbon footprint reduction. The main contribution is to indicate the potential benefits for the natural environment associated with the use of cloud computing and to discuss the aspects related to reducing the carbon footprint of cities using cloud computing.

Our research methodology is divided into two parts:

1. Literature review related to cloud computing, carbon footprint and smart cities.

2. Performing a survey related to using a modern ITC solutions in cities, including carbon footprint issued.

3. Discussion of results, limitations of research and conclusions.

The paper is divided as follows. The first part presents the outline of the use of cloud computing in city management. Next, we present the carbon footprint of the organization and the potential benefits of cloud computing in reducing the carbon footprint in cities. The last part presents the analysis and discussion of results of research and conclusions.

\section{Outline of the Use of Cloud Computing in City Management}

Among many directions of information technology development widely discussed and emphasized in the literature on the subject, cloud computing plays a particularly important role, redefining the approach to how IT solutions can be produced, offered, delivered and developed by IT suppliers, and by recipients (organizations and private persons)_-purchased, used and accounted. For many types of organizations (including cities), the cloud computing model fundamentally changes the approach to IT resource management, making it possible to replace or supplement own and locally organized IT solutions-with a set of IT services offered by specialized external suppliers. The emergence and development of cloud computing was mainly due to the growing possibilities of processing and storing large amounts of data along with systematically decreasing costs of ICT equipment purchase, universal access to the high-speed Internet network, popularity of IT outsourcing and competition on the IT market. The intention of cloud computing is to provide IT services to recipients in a mass manner, in a similar way to the use of various media, i.e., water, electricity, electricity, gas, telephony and television [12].

The concept of cloud computing is variously defined in the literature on the subject. According to NIST, "Cloud computing is a model for enabling ubiquitous, convenient, on-demand network access to a shared pool of configurable computing resources (e.g., networks, servers, storage, applications, and services) that can be rapidly provisioned and released with minimal management effort or service provider interaction" [13]. According to Haag and Cumming "cloud computing is a technology model is which any and all resources-application software, processing power, data storage, backup facilities, develop- 
ment tools ... literally everything-are delivered as a set of services via the Internet" [14]. According to another definition "Cloud Computing is an IT service model where computing services are delivered on demand to customers over a network in a self-service mode, independent of device and location" [15]. Cloud computing is a distribution model for ICT solutions which, being available to recipients via the network (most often the Internet), are characterized by high availability, flexibility and reliability, and which are paid for taking into account the actual consumption of resources and the use of the service. A prerequisite for using cloud computing services is the necessity to have an electronic device with Internet access (e.g., laptop, mobile phone, desktop computer) for entering/displaying data [16].

The cloud computing offers subscription-oriented services, which are available ondemand over the Internet to host users' applications. The components of cloud data centers (CDCs), including servers, network devices, and storage devices, have to be run $24 / 7$ in order to ensure the availability and reliability of the services [17]. Responsibility for the proper functioning of IT solutions made available in the cloud to many recipients rests with the provider, who has tools to facilitate the measurability and accountability of services used by a given recipient. The NIST draft definition goes on to describe deployment models (Private, Community, Public and Hybrid Cloud), characteristics of cloud computing (ondemand self-service, broad network access, resource pooling, rapid elasticity and measured service), and service models (Software as a Service-SaaS, Platform as a Service-PaaS and Infrastructure as a Service-IaaS)—see Figure 1.

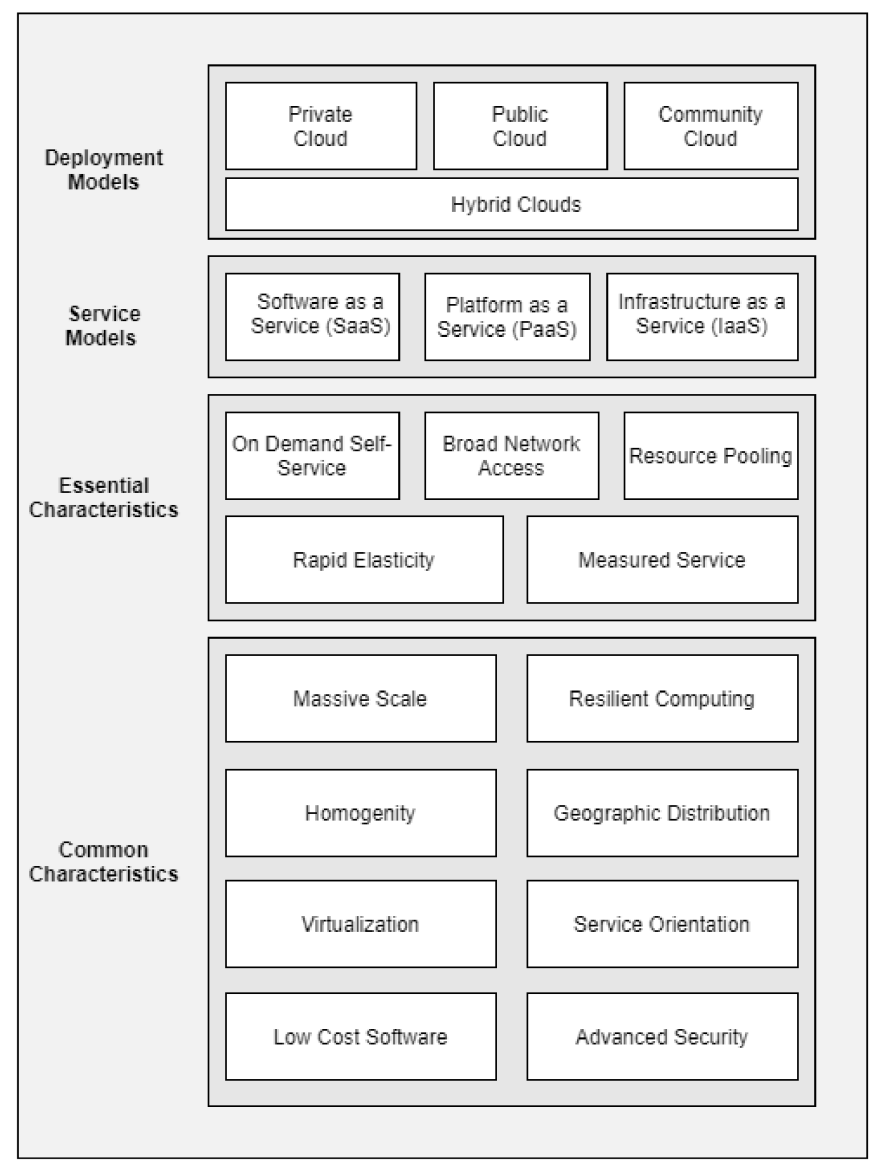

Figure 1. Deployment models, service models and characteristics of cloud computing [13].

Cloud computing offers recipients various options for the purchase and use of IT solutions, which are varied and dynamically adjusted in terms of reported needs. It is also possible for the organization's traditionally acquired and operated IT solutions to coexist with IT resources available and operated in the computing cloud. The analysis 
and application of a given model and type of cloud computing will result from the needs, specificity and capabilities of a given organization. It is also necessary to conduct a thorough analysis of the benefits and risks associated with the implementation of a given model and type of cloud computing in the organization. The list of potential benefits and threats of the cloud computing model is presented in Table 1.

Table 1. Benefits and threats of cloud computing services $[18,19]$.

Benefits

- $\quad$ Need to purchase expensive hardware and software (low entry costs) and no need to maintain and develop specialized rooms with equipment (allocating the saved funds for other business purposes),

- Relatively lower costs of acquiring, maintaining and developing IT resources (fees only for the resources used),

- Greater predictability of IT costs,

- Quick access to the necessary IT resources from anywhere and at any time,

- Lower demand for IT staff,

- Reduction of investment risk in the field of information and communication technologies,

- High scalability and efficiency of shared IT resources,

- Transferring responsibility for the functioning and development of IT resources to the supplier,

- High level of IT resources security (including negligible failure rate, high availability and reliability, various data backup locations, systematic and automatic updates, comprehensiveness and systematic protection measures, certifications, data protection standards, redundancy of power supply, internet connections and other components),

- Professional technical support and service provided by the supplier,

- Simplicity of use of IT resources (the interface is a web browser),

- The possibility of using functional IT solutions that allow you to compete with larger entities and create innovation.

\section{Threats}

- Certain problems related to security of collected and processed data (concerning, e.g., data storage place, separation of client data, access control, data encryption and confidentiality, disaster recovery, etc.),

- Internet network failures limiting or preventing the use of IT resources, Partial or complete dependence on the provider (lack of control over the provider's actions),

- Risk of cooperation with an unprofessional provider,

- Vulnerability of solutions offered in a cloud to cyberterrorism or intelligence activities,

- Possibility of sudden termination of activity and provision of services by the provider,

- Some difficulties in adaptation of the offered IT services to the client's needs,Difficulties associated with data migration in the event of a change of provider,

- $\quad$ Relatively high costs of broadband Internet connections enabling use of services,

- $\quad$ Limited possibilities to integrate local and external IT resources,

- $\quad$ Complexity of managing IT services across multiple vendors,

- $\quad$ Possible legal problems (different regulations in different countries, unfavorable contractual provisions, unsatisfactory provisions in the case of a serious breakdown or a provider's bankruptcy, lack of best practices, etc.).

Awareness of the benefits and actions to reduce threats in the use of cloud computing solutions will undoubtedly increase the popularity of cloud computing among various types of organizations (including cities), facilitating their dynamic and flexible functioning. The development of the IT services market and progress in the field of ICT will probably affect not only the emergence of new cloud computing properties, but also the creation of completely new or evolution of existing services available in the cloud. It should be emphasized that cloud computing is already widely used in such areas as: IoT (internet of things), social media, e-commerce or media streaming, which are also increasingly used in various types of organizations $[20,21]$.

\section{Carbon Footprint of the Organization}

Climate change has resulted in various activities for environmental protection initiated by governments, non-governmental organizations, cities, municipalities and typically business organizations. The activities undertaken include initiatives aimed at reducing greenhouse gases (GHG) - mainly carbon dioxide, reducing energy consumption as well as monitoring, analyzing, reporting and forecasting the effects of climate change. Carbon footprint (CF) is one of the tools that helps to estimate the impact of a given product, activity, person, organization or country on environmental change is the carbon footprint (CF) $[22,23]$. 
Generally, the carbon footprint concept deriving from the term of ecological footprint [12] and has been introduced in the 90s. The carbon footprint is connected to the climate change impacts' measurement and addresses the human activities' impact on the environment. It is mainly related to greenhouse gas emissions (carbon emissions) [9]. The carbon footprint allows for measuring the exclusive total amount of carbon dioxide emissions caused (directly and indirectly) by an activity or is accumulated over the life cycle of a product [24]. According to Carbon Trust-a products' life cycle carbon footprint (CF) is a measure of the total greenhouse gas emissions generated by this product, starting from extraction of raw-materials and ending at the end of the products' life cycle, in a unit of measurement of carbon dioxide equivalents, which means that the consumption of all greenhouse gases is standardized and converted into tons of environmentally harmful carbon dioxide. Although there is no explicit method for measuring $\mathrm{CF}$, it is assumed that calculating the carbon footprint is one of the known and effective tools for monitoring greenhouse gas emissions that have a significant impact on climate change [25]. In addition, it is noted that the carbon footprint is the most reliable, measurable and international tool that gives comparable results to organizations from around the world in the same sector [26]. Basically, the measurement of the total amount of greenhouse gases caused by direct and indirect activity of the organization covers three ranges [27]:

- Direct emissions-the effect of fuel combustion and technological processes,

- Indirect emissions-the result of electricity consumption,

- Other indirect emissions throughout the production cycle, e.g., from the production and transportation of raw materials or semi-finished products and their use by end customers.

Today, many individuals and organizations (as well as cities, municipalities, provinces, and whole countries) decide to calculate their carbon footprint. This is mainly due to the growing importance of the idea of sustainable development, one of the areas of which is to calculate the carbon footprint and determine the negative impact on the environment (identification of areas with high GHG emissions) and then take action to reduce greenhouse gas emissions. An important aspect of determining and publishing the $\mathrm{CF}$ is also image considerations and presenting the organization and/or its products as interested in reducing its negative impact on the environment. Increasingly, customers are looking at the environmental impact of organizations or their products when making a decision to purchase a product or service. Other reasons for calculating the carbon footprint of organizations may also include [26]:

- Market requirements-currently, many entities and organizations in Poland are obliged to calculate the carbon footprint of their activities or products due to their obligations towards their business partners and cooperation in international markets. Thus, these are mainly international entities (usually with greater ecological awareness and knowledge) and organizations that participate in supply chains in which entities, requiring their partners to provide the size of CF. If a product of a given organization has a lower carbon footprint than a competitor's product, it proves the producer's responsibility to protect the natural environment and optimize processes which, apart from saving greenhouse gas emissions, usually bring financial savings, creating opportunities for development, improvement of energy efficiency, and changes. In management methods, etc., the size of CF may also become an important criterion in tenders. In addition, more and more investors are not supporting investments that depend on fossil fuels or that have significant and negative environmental consequences.

- The need to report to the CDP (Carbon Disclosure Project)—which is an international not-for-profit organization that has created a global system for organizations and cities, enabling them to calculate, disclose, manage and share their comprehensive information on environmental activities. CDP operates in all sectors, motivating entrepreneurs to pro-environmental activities and sharing achievements in reducing greenhouse gas emissions. 
- The growing importance of Corporate Social Responsibility (CSR) and non-financial reporting-focusing on taking action and investing in human resources, environmental protection and relations with stakeholders who may have a real impact on the effectiveness of economic activities of these organizations, and their innovation. Guided by these values, organizations and managers reporting their sustainable development strategies are putting more and more emphasis on environmental aspects.

Organizations undertaking wide-ranging activities to reduce their carbon footprint may, as a result, achieve not only reduction of carbon dioxide emissions, but also reduce expenditure on the resources used (e.g., electricity, water). Reducing the carbon footprint is a challenge for all cities, municipalities, organizations, societies and countries around the world that must analyze their activities and practices in order to reduce their negative impact on the environment and rationally shape and manage its resources. As a result of the measures introduced, it will be possible to protect the Earth's natural resources, reduce greenhouse gas emissions and, in the long run, reduce the impact on global warming and climate change. Today, many countries, institutions and companies have pledged to reduce their emissions, and the EU has even set a target of achieving 'climate neutrality' by 2050.

One of the most important methods of determining and verifying CF is the ISO 14067 standard and its technical specification from 2013, which analyzes the potential impact on the environment taking into account the entire life cycle assessment (LCA) of a product, but can also refer to a process, service or system [27]. This assessment takes into account the various stages, starting from the extraction of the necessary raw materials, through design, production, distribution, use and disposal. Determining the CF enables the determination of GHG emissions at each stage of the production process along the entire supply chain, therefore it takes into account both the direct aspects influenced by the organization and those indirectly caused by other entities with which it cooperates. The use of ISO 14067 to determine CF will enable [27]:

- Providing information for consumers and other parties on their impact on the environment,

- Increasing the environmental awareness of consumers and engaging them in environmental issues,

- Supporting organizations to track climate change,

- Supporting the implementation of a climate change management policy.

The accuracy of CF calculation depends on the quality of the collected data, which can be collected as part of own measurements and calculations and obtained from electronic databases and studies of organizations and institutions dealing with environmental protection issues and having developed methodologies for calculating the carbon footprint in relation to organizations, products and services. There are also CF calculators (most often available on websites) which, depending on the adopted methodology and scope, can approximately help determine the impact of a given organization, process, product or service on the environment. The ability to determine the CG index allows organizations to have a preliminary idea of their impact on the natural environment and make informed and responsible decisions aimed at reducing greenhouse gases.

\section{The Potential Benefits of Cloud Computing in Reducing the Carbon Footprint in Cities}

It is obvious that the dynamic increase in saturation and the widespread use of information and communication technologies (ICT) in city management, business, but also other aspects of human life, results in an increased demand for electricity. Consequently, the increasing electricity required for the use of various ICTs by cities, organizations and entities results in increased emissions of carbon dioxide and other greenhouse gases into the atmosphere. Despite the fact that new information and communication technologies have a positive impact on the natural environment, e.g., reducing paper consumption, using videoconferences instead of distant trips or air flights, and introducing smart grids in order to save electricity - the dynamically developing ITC market has become a significant consumer of electricity in recent years. According to Greenpeace-in 2012, the IT sector consumed more electricity than the entirety of Russia and just under half the total consump- 
tion of the US [28]. Computing produces about 3\% of the world's carbon dioxide emissions, therefore the carbon footprint is very important issue in computing [29]. However, the concept of a carbon footprint goes beyond the mere electricity consumption of products. It covers the emission of greenhouse gases throughout the life cycle of a product-from obtaining raw materials, through production, assembly and transport, to operation and disposal of the device. More specifically, the ICT sector's carbon footprint covers both mobile and fixed networks, data centers and corporate networks, as well as all devices such as phones, computers, routers and switches, Internet of Things devices and more. According to the research by Ericsson - the total carbon footprint of the ICT sector in the life cycle is around 730 million tonnes of $\mathrm{CO}_{2}$ equivalent (Mt CO2-eq). It corresponds to $1.4 \%$ of total global greenhouse gas emissions [30]. According to Lean ICT—global greenhouse gases emissions generated by ICT has increased from $2.5 \%$ to $3.7 \%$ of global emissions since 2013. In OECD countries, since 2013, the $\mathrm{CO}_{2}$ emissions generated by ICT increased by about 450 million tons. Overall, $\mathrm{OECD} \mathrm{CO} \mathrm{CO}_{2}$ emissions decreased by 250 million tons over the same period [31]. The ICT sectors carbon footprint overtaking air travel's 2.4\% [32]. Other studies show that the digital sector's energy consumption (including the production and usage of devices, data storage and traffic) is increasing by $9 \%$ per year. It corresponds to $3.3 \%$ of the world's economic electricity consumption in 2020 (vs. 1.9\% in 2013). The ICT was generated 3.3\% of global GHG emissions in 2017. It exceeds a civil aviation (2\%), often considered as one of the biggest GHG emitters. It is expected to increasing GHG generated by ICT to $4 \%$ in 2020 [33]. General estimates indicate that in the next decade as much as $51 \%$ of electricity may be consumed by information and communication technologies [34].

Cloud computing offers some opportunities to reduce energy consumption and reduce greenhouse gas emissions from different types of ICT. Generally, organizations using cloud computing use only the resources necessary at a given time (computing power, disk space, etc.), which may reduce energy consumption compared to the use of the organization's own servers. The NDRC report highlights that a typical large-scale cloud provider achieves around $65 \%$ server utilization rates compared to $15 \%$ locally. Consequently, far fewer machines are in use, which "represents an $84 \%$ reduction in power required. As a result, it can be seen that there is a potential for cloud computing in the field of environmental protection (energy efficiency) compared to the use of classic, i.e., own, organizational infrastructure" [35]. According to Capgemini, cloud computing may be safer for the environment compared to the local infrastructure of the organization due to [34]:

- Automation and autonomous adaptation of computing power to the current demand,

- Real-time sharing of computing power,

- Archiving and keeping archived data with long periods without access in the so-called 'sleep' mode,

- More effective cooling and heat recovery from cooling devices,

- Allocation of data centers in locations where the system produces surpluses,

- The so-called for example, close to large wind farms or high-efficiency solar power plants.

The use of cloud computing can alleviate environmental problems thanks to more efficient use of equipment, building data centers based on energy-efficient servers and ecological energy sources. Cloud computing also enables wide application in the organization of remote work, which reduces the need for personnel to commute to work and thus reduces carbon dioxide emissions. The transfer of data from the own server room of various types of organizations (including city and municipal offices) to the public cloud looks particularly favorable for the environment, which is influenced by such factors as greater load flexibility, better server utilization rates (high virtualization rates) and more energy-efficient supplier infrastructure (which is done, among others, by using new and efficient IT equipment, using efficient high-density systems, etc.).

Overall, it is estimated that moving commonly used applications to the cloud would reduce energy consumption by $87 \%$ and the saved energy could be used to power Los Angeles for a year [36]. Similar analysis results are presented by Accenture, which shows that even partial migration to the cloud can reduce carbon dioxide emissions by over $84 \%$ 
compared to traditional infrastructure. The Accenture report shows that migrations to the public cloud can reduce $\mathrm{CO}_{2}$ emissions by 59 million tons per year which equates to taking 22 million cars off the road. However, the positive environmental effects of using a public cloud also depend on the supplier's proper approach to reducing carbon dioxide emissions and having the necessary sustainability practices in, e.g., planning, building, powering, operating and decommissioning its data centers [37]. The proposals of various activities and possibilities of cloud computing to reduce carbon dioxide emissions in comparison to the organization's own infrastructure are presented in Figure 2.

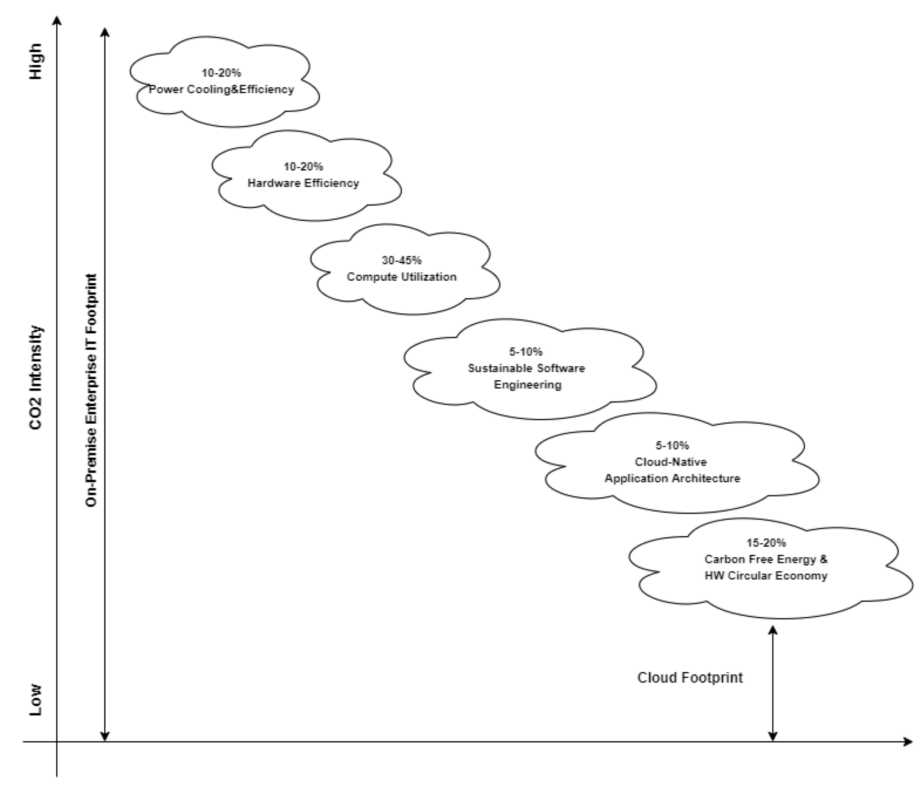

Figure 2. Activities and possibilities of cloud computing to reduce carbon dioxide emissions compared to the organization's own infrastructure [37].

Cloud computing can, therefore, contribute to reducing the use of energy on a global scale. The results of research performed by Pike Research make it possible draw to a conclusion that cloud computing could allow up to 38 percent reduction in usage of energy in the world's data centers by 2020. It also estimates an increase in the use of cloud computing will decrease energy consumption from the rate of 2018 TWh to a 2020 rate of 139.8 TWh. It results in a 28 percent reduction in greenhouse gas emissions in the next five years [38].

Taking action by large public cloud providers in the field of sustainable development, despite a significant increase in data processing, allows them to reduce electricity consumption. Often times, modern and large data centers of public cloud providers provide more efficient cooling and enable heat recovery and reuse in a cost-effective manner. According to Google, the amount of computing in owned data centers increased by $550 \%$ between 2010 and 2018, but the increase in energy consumption was only 6\% [39]. Due to the significant heat emitted by computer equipment and the significant costs of cooling them (according to the estimates of the ABB research center, as much as $40 \%$ of the energy used by data centers is used only for powering cooling systems) - an interesting initiative is to locate a data center offering cloud computing services in locations with a low average annual temperature (e.g., in the polar regions) and the use of hydropower. Such activities will reduce energy costs by up to $60 \%$. Another practice is to locate data centers in places where the surplus of the so-called clean energy, for example close to large wind farms or high-efficiency solar power plants [34]. The use of renewable energy sources plays a key role in reducing the negative impact on the environment in data centers. Data centers (e.g., Green Earth Data and GreenQloud) are already emerging to ensure that they use $100 \%$ renewable energy (e.g., geothermal resources) [40]. It should also be emphasized that the effective organization of IT infrastructure carried out by providers of public cloud 
services can have a positive effect on the natural environment by reducing the amount of IT equipment waste from utilization. Examples of pro-ecological actions taken by leading public cloud providers along with their carbon footprint are included in Table 2.

Table 2. Pro-ecological activities (reduction of $\mathrm{CO}_{2}$ emissions) of major cloud computing providers [41-44].

Major Cloud Computing Vendors and Their Efforts to Reduce CO2 Emissions

\section{Google}

- Declaration of carbon neutrality since 2007 (however, some estimates show a carbon footprint in 2018 of 1.2 megatons of carbon dioxide, which can be compared to the carbon footprint that Liberia generated).

- $\quad$ Since 2009, the company has powered all of its operations (including Google Cloud Platform) with renewable energy. Since 2017, it has funded increases in electricity consumption by sourcing the same amount of renewable energy. By 2030, it is making it mandatory to use only $\mathrm{CO}_{2}$-free energy in its data centers worldwide. Through the use of artificial intelligence and machine learning, the amount of energy consumed by air conditioning systems is reduced by up to $40 \%$ and energy efficiency is increased to $15 \%$. Construction of a data center on the Gulf of Finland fully cooled using seawater. Establishing a subsidiary company, Google Energy, that can purchase electricity directly from independent renewable energy producers (harvesting energy from wind and solar).

\section{Microsoft}

- Ensure that all operations including owned data centers have carbon neutral status.

- The company aims to power all of its data centers with $100 \%$ renewable energy by 2025 , have a negative carbon footprint and eliminate its dependence on diesel by 2030, and remove more carbon dioxide from the environment by 2050 than it has emitted since the company was founded (i.e., since 1975). To take advantage of a natural source of cooling for IT equipment, Project Natick (the installation of a data center underwater, more specifically on the seabed near Scotland's Orkney Islands) was launched. Established the Transform to Net Zero initiative with eight companies to work to accelerate business efforts toward a zero carbon economy with transparency and science. Developing a Sustainability Calculator-providing information on the total carbon emissions resulting from the use of cloud computing.

\section{Amazon}

- $\quad$ Carbon footprint in 2018 - emitting 44.4 megatons of carbon dioxide, which is as much as Finland emitted in 2019.

- $\quad$ The company intends to completely switch to renewable energy by 2030. The company will achieve carbon neutrality by 2040. In 2030 100,000 Rivian electric delivery vehicles will be purchased to equip Amazon's logistics centers, which will contribute to reducing carbon dioxide emissions. Financing environmentally friendly activities (e.g., reforestation).

A significant part of the actions taken mean that the public cloud can be called "Green Computing", because key suppliers adopt and apply a policy such as the organization and operation of IT solutions to minimize the carbon footprint. Currently, smaller providers of public cloud computing solutions are also taking decisive steps to reduce $\mathrm{CO}_{2}$ emissions. As a result of the actions taken, the energy efficiency of cloud computing improves, but also the consumption of hazardous materials is reduced and the possibility of recycling or biodegradation of IT products and waste increases.

\section{Analysis of Research Findings}

In the first half of 2021, the authors of this paper conducted a study on the application of information and communication technology (ICT) in dynamic urban management including carbon footprint issues. The research questionnaires were divided into several parts. One of them concerned the IT infrastructure owned by the office, the services implemented through IT and the possibility of using the cloud computing model. This part of the research form was optional. Respondents did not have to complete it.

The research questionnaires were addressed to town halls on the list of the largest towns in Poland. Cities in positions 1-10 were omitted, as they were surveyed as part of other smart city studies. Instead, the focus was on positions 11 to 40 (the largest city had 292 thousand inhabitants, the smallest one 94 thousand). The optional portion of the survey form was completed by only five respondents. Originally, it seemed that such a research sample was insufficient. However, after analyzing them, it turned out that the results obtained are very similar. City halls have very similar IT solutions. Therefore, it may be concluded that the remaining town halls use similar tools and services. This is most likely due to the fact that they are subject to similar procedures and legal regulations. 
City halls, despite their great independence, function in a similar way. They implement the same processes and use similar technological solutions.

A synthetic presentation of the research results is presented in Table 3.

Table 3. A synthetic presentation of the research results.

\begin{tabular}{|c|c|c|c|c|c|c|}
\hline City & $\begin{array}{l}\text { Number of } \\
\text { Server Rooms } \\
\text { at City Hall }\end{array}$ & $\begin{array}{l}\text { Number of } \\
\text { Servers in Use }\end{array}$ & $\begin{array}{c}\text { Has the City } \\
\text { Audited Its } \\
\text { Energy } \\
\text { Consumption in the } \\
\text { IT Area? }\end{array}$ & $\begin{array}{c}\text { Has the City } \\
\text { Analyzed the IT } \\
\text { Footprint? }\end{array}$ & $\begin{array}{l}\text { How do you } \\
\text { Use the } \\
\text { Servers? }\end{array}$ & $\begin{array}{c}\text { Is the City } \\
\text { Planning to Move } \\
\text { Services to the } \\
\text { Cloud? }\end{array}$ \\
\hline $\mathrm{C} 1$ & 3 & 10 & No & No & $\begin{array}{c}\text { Each service on } \\
\text { a separate } \\
\text { server }\end{array}$ & No \\
\hline $\mathrm{C} 2$ & 2 & 10 & No & No* & $\begin{array}{l}\text { Partial server } \\
\text { virtualization }\end{array}$ & Selected services \\
\hline $\mathrm{C} 3$ & 3 & 9 & No & No & $\begin{array}{c}\text { Each service on } \\
\text { a separate } \\
\text { server }\end{array}$ & No \\
\hline $\mathrm{C} 4$ & 3 & 8 & No & $\mathrm{No}^{*}$ & $\begin{array}{l}\text { Partial server } \\
\text { virtualization }\end{array}$ & No \\
\hline C5 & 1 & 7 & No & No & $\begin{array}{c}\text { Each service on } \\
\text { a separate } \\
\text { server }\end{array}$ & No \\
\hline
\end{tabular}

The results of the survey form from each city are labelled C1 through C5. The survey was intended to be anonymous. As can be seen from the data in Table 3, all surveyed cities have extensive server infrastructure. The number of servers in use varies from 7 to 10. These quantities are a direct result of the services and needs of an office. The most common are servers used to support the city's information systems: budget management, financial management, tax calculation, fee records, etc. Respondents also indicated the need to use servers for document circulation management systems, providing disk resources for employees, database management, etc. Some infrastructure is also necessary for the integration of services with external systems such as ePUAP (electronic communications with the public administration) or GIS (Geographic Information System).

None of the cities audited their IT solutions in terms of energy consumption. The respondents admit that the amount of electricity consumed in the server room (servers, network infrastructure, air conditioners) is accepted as it is. The costs generated in this area are not a significant point of the city budget. It should be noted, however, that energy intensity is taken into account when planning purchases of new servers. At the same time, the respondents indicate that the useful life of the server is 5 to 10 years.

The situation is similar in the area of carbon footprint. The respondents admit that they have never considered what carbon footprint the ICT infrastructure leaves behind. In two cases (marked with * asterisk), respondents admitted that the city publishes carbon footprint reports. However, these reports cover the whole city. There are no specific references to ICT solutions.

The survey went on to ask about how servers are used. Most city halls have adopted policy that each subsequent service is run on a dedicated machine. In two cases, the respondents admitted that in their case there is partial virtualization of the server environment; however, it is limited.

The last question of the survey form concerned the possibility of migrating the server environment to cloud computing. The respondents admitted that they are not interested in this type of solutions. This is mainly due to the fear of losing the full control over databases and information resources. Cloud computing is treated as a solution with limited security. Some of the respondents also pointed to the legal regulations which, according to them, 
do not allow to move the information resources concerning the city, residents, equal type or investors outside the IT infrastructure of the office. Moving some services only to the cloud is considered to be the only one of the surveyed entities.

On the basis of the research results obtained, it is difficult to exactly determine the potential for reducing the carbon footprint generated by the infrastructure of city offices. This is mainly due to the fact that IT departments do not study the energy consumption of their IT infrastructure. One can only attempt to perform an analysis at some level of approximation.

The issue of testing energy consumption of servers is addressed to the manufacturers of such solutions and a number of other organizations, including non-profit organizations. One of them is SPEC (Standard Performance Evaluation Corporation). Both leading server vendors (e.g., Dell, Fujitsu Siemens, IBM and Sun) and processor companies, including Intel and AMD, participated in the development of the benchmark.

The Standard Performance Evaluation Corporation (SPEC), was founded in 1988 by a small number of workstation vendors. They perceived that the marketplace needs realistic, standardized performance tests. SPEC was developed to recognize standardization of the organization with more than 60 member companies. Each quarter, SPEC publishes several hundred different performance scores covering different system performance disciplines. The aim of SPEC is to ensure that the market has a fair and useful set of indicators to distinguish between candidate systems. The path taken is an attempt to balance strict compliance and to allow the retailers to demonstrate their merits. The assumption is a good test, which is reasonable to perform a higher level of availability of results in the marketplace [45].

As follows, an attempt will be made to calculate the energy consumption of a sample server infrastructure located in a city office. Some simplifications have been made in the calculations, which result from the answers and discussions with the respondents. They acknowledged that some of the server infrastructure is new and some has been in use for several years. Based on reports from benchmark systems, it can be assumed $[45,46]$ that:

- The new server from the above consumes $40 \mathrm{~W}$ at rest and $90 \mathrm{~W}$ under load,

- Older servers consume $140 \mathrm{~W}$ at idle and $240 \mathrm{~W}$ under load.

If one assumes that half of the servers are new and the other half are several years old, and that half of the time they are running at rest and half under load, this means that a server room in a medium-sized city (90 to 200 thousand inhabitants) consumes:

- $\quad$ New servers $65 \mathrm{~W} \times 5$ servers $=325 \mathrm{~W}$.

- $\quad$ Old servers $190 \mathrm{~W} \times 5$ servers $=950 \mathrm{~W}$.

In total, the servers consume $1300 \mathrm{~W}$ of power. To this power consumption one should add about $50 \%$ declared by the respondents for network infrastructure (switches, routers, etc.). This gives another $650 \mathrm{~W}$.

Cooling systems and air conditioners are an important part of server room equipment. A typical solution for a server room is a $5-6 \mathrm{~kW}$ air conditioner. It is estimated that such a device consumes on average $500 \mathrm{~W}$. Assuming that in each server room one air-conditioner is installed, another $1500 \mathrm{~W}$ of power should be added to the above calculations.

In total, the servers with the infrastructure and cooling consume $3450 \mathrm{~W}$ of electrical energy. With this power consumption, the consumption is estimated at $82.8 \mathrm{kWh}$ per day. Therefore, the annual consumption will be $30,222 \mathrm{kWh}$.

Using the electricity conversion factor for Poland [47], each MWh of electricity produced emits $758 \mathrm{~kg}$ of $\mathrm{CO}_{2}$. It is possible to calculate the emission factor of an example server room. For $30 \mathrm{MWh}$ per year, the emission factor is $22,740 \mathrm{~kg}$ of $\mathrm{CO}_{2}$.

To the above estimated calculations, one should add the $\mathrm{CO}_{2}$ emission connected with the production of IT equipment. According to estimates, only $55 \%$ of the emissions come from the usage of the equipment. Additionally, $45 \%$ of the total emissions is dedicated to the production of digital equipment [48]. Therefore, assuming an average server usage 
time of 8 years, $1 / 8$ of $22740 \mathrm{~kg}$ of $\mathrm{CO}_{2}$ should be added to the above calculation. This gives a total of $25582 \mathrm{~kg}$ of $\mathrm{CO}_{2}$ per year.

The calculations made are for just one city office. The average daily current consumption in the server room of the $i$-th city (UPPj) can be calculated from the formula:

$$
\begin{gathered}
U P P_{i}=\sum_{j=1}^{n}\left(\left(P M S_{j} * T s_{j}\right)+\left(P M O_{j} * T o_{j}\right)\right)+\sum_{k=1}^{m}\left(\left(P M S_{k} * T s_{k}\right)+\left(P M O_{k} * T o_{k}\right)\right) \\
+\sum_{z=1}^{p}\left(\left(P M L s_{z} * T s_{z}\right)+\left(P M L o_{z} * T o_{z}\right)\right)+\sum_{l=1}^{s}\left(P M K_{l} * T_{l}\right)
\end{gathered}
$$

where:

$P M S_{j}$-approximate power consumption by the $j$-th new type server in the idle state (in $\mathrm{kW}$ ).

$T s_{j}$-average working time of $j$-th server in idle state (in $\mathrm{h}$ ).

$\mathrm{PMO}_{j}$-approximate power consumption by the $j$-th server of the new type under load (in $\mathrm{kW}$ ).

$\mathrm{To}_{j}$-average working time of $j$-th server in load state (in h). (in $\mathrm{kW}$ ).

$P M S_{k}$-approximate power consumption by the $k$-th old type server in the idle state

$T s_{k}$-average working time of $k$-th server idle (in h).

$P M O_{k}$-approximate power consumption by the $k$-th old type server under load (in $\mathrm{kW}$ ).

$\mathrm{To}_{k}$-averaged working time of the $k$-th server under load (in h).

$P M L s_{z}$-approximate power consumption of the $z$-th IT device (network or peripheral) at rest (in $\mathrm{kW}$ ). (in h).

$\mathrm{Ts}_{z}$-averaged working time of the IT device (network or peripheral) in the idle state

$P M L o_{z}$-approximate power consumption of the $z$-th IT device (network or peripheral) under load (in $\mathrm{kW}$ ).

$\mathrm{To}_{z}$-averaged working time of the IT device (network or peripheral) under load (in h).

$P M K_{l}$-approximate power consumption of the $l$-th air conditioner (in $\mathrm{kW}$ ).

$T_{l}$-average operation time of the $l$-th air conditioner (in h).

Based on statistical data, there are 30 cities in Poland with a population between 100 and 300 thousand inhabitants (cities included in the survey; cities at positions 11 to 40 on the list of the largest in Poland). Therefore, the obtained estimates should be multiplied times 30. The amount of $\mathrm{CO}_{2}$ emitted in those cities and the potential environmental benefits related to the migration of the server environment to cloud computing are presented in the graph in Figure 3. $\mathrm{CO}_{2}$ emission savings assuming an $85 \%$ reduction, according to the Accenture 2020 study.

As the chart shows, 30 cities in Poland can emit 780 tons of $\mathrm{CO}_{2}$ per year. These are quantities that cannot be underestimated. Of course, $\mathrm{CO}_{2}$ production in other industries is much higher, but modern cities need to be aware of the magnitude of $\mathrm{CO}_{2}$ emissions and the possibility and necessity of reducing them. Using the cloud computing model would reduce the carbon footprint to about 117 tons per year. This approach would yield over 600 tons of savings. This equals about an $85 \%$ reduction of the carbon footprint.

To the above estimates, we should add the cities on the list of the 10 largest in Poland, which probably have much more developed IT infrastructure. One should not forget about the remaining 900 cities in Poland, of which over 250 are urban gminas, including 25 cities with powiat rights. 


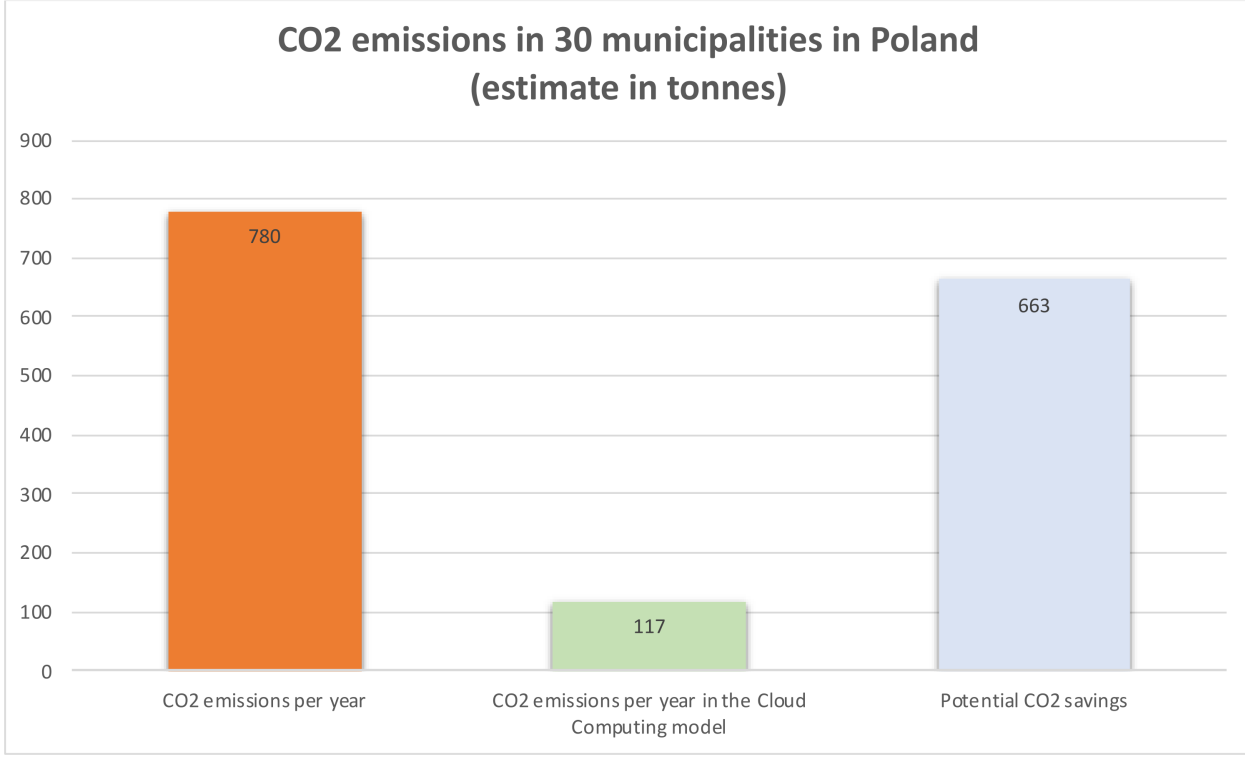

Figure 3. $\mathrm{CO}_{2}$ emissions in 30 municipalities in Poland (estimate in tonnes).

All the above calculations concern cities located on the territory of Poland. It is all the more important because Poland has one of the highest $\mathrm{CO}_{2}$ emission indices in Europe. Emissions in other countries are lower, but there are countries with a much bigger population and number of cities. European countries with a larger population than Poland include: Germany, France, Great Britain, Italy, Spain and Ukraine [49]. The relevant $\mathrm{CO}_{2}$ emission factors are presented in the graph-Figure 4.

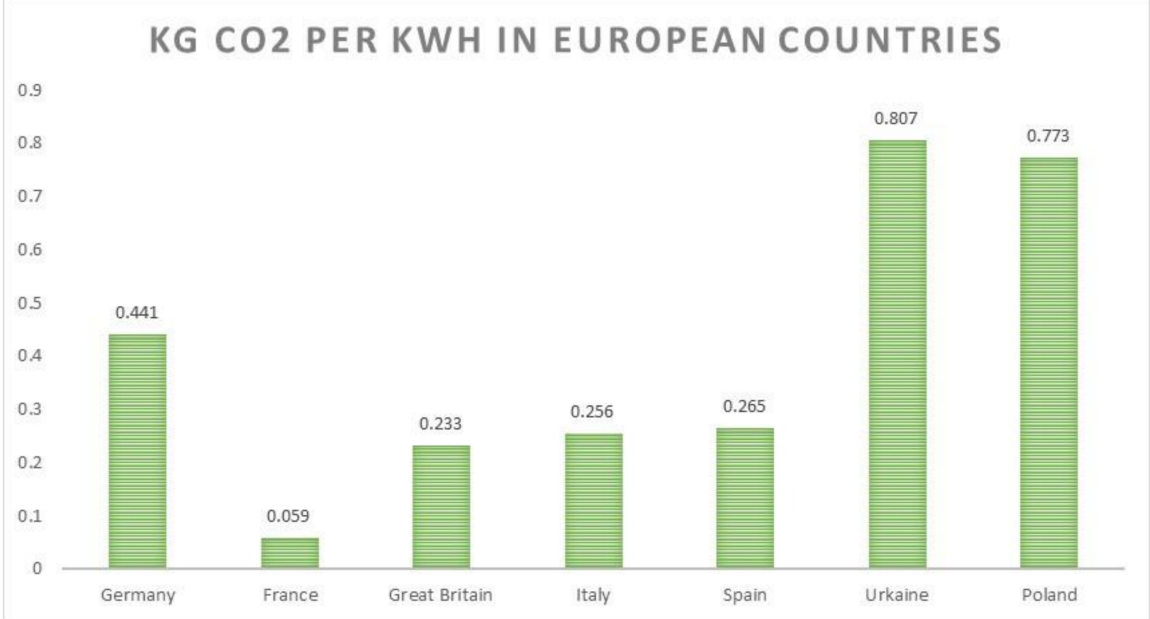

Figure 4. $\mathrm{Kg} \mathrm{CO}_{2}$ per $\mathrm{kWh}$ in European Countries [49].

The emission factors show that similar IT infrastructures located in city halls of most European countries will generate much less $\mathrm{CO}_{2}$ than in Poland. The only exception is Ukraine, which, similarly to Poland, has an energy system based on hard coal and has a higher emission index in relation to the countries presented in the diagram.

\section{Conclusions}

In the available literature, few publications deal with the subject of estimating $\mathrm{CF}$ and determining $\mathrm{CO}_{2}$ emissions for IT technologies used in Polish cities. Given the different levels of computerization in large, medium and small Polish cities, the dynamic development of information and communication technologies and the increasing offer of IT services 
provided in the cloud computing model, it is advisable to undertake research presenting the possibilities of using cloud computing in Polish cities, highlighting the various benefits (including those of an environmental nature) and threats connected with such a form of acquisition and use of IT solutions.

The conducted analyses show that transferring IT services to cloud computing and resigning from maintaining local server rooms may significantly affect the reduction of $\mathrm{CO}_{2}$ emissions and reduce $\mathrm{CF}$ for cities in Poland. Despite the lack of interest of representatives of all cities in using cloud computing (which results mainly from legal problems and security issues) - it can be stated that even a partial transfer of selected IT services of a given city and exclusion of servers necessary for their operation in local server rooms of the cities will reduce $\mathrm{CO}_{2}$ emissions and $\mathrm{CF}$ of a given city. Reduction of $\mathrm{CO}_{2}$ emission may also result from designing and launching a private computational cloud of a given city or a community cloud (for a group of cooperating cities sharing the same goals) in a sustainable way. Considering restrictive environmental requirements when creating the above types of clouds may positively affect the reduction in $\mathrm{CO}_{2}$ emissions. The task of building a community computational cloud (safe both for the processed data and the environment) for many cities in Poland should be of interest to the central state administration. The indicated state administration units should carry out the migration of IT services of individual cities to the computational cloud in accordance with the adopted strategy and policy of informatization of information resources, which should comprehensively take into account the issues of reducing $\mathrm{CO}_{2}$ emissions and $\mathrm{CF}$. Undertaking the migration of IT services to the computing cloud by cities in Poland may (and even should) be supported by EU funds, which can finance such large, complex and costly programs of modernization and digital transformation of public administration.

For cities that do not decide to move all or part of their services to the cloud, an important role will be played by planning, designing and developing local server rooms and the IT infrastructure located there in a way which is appropriate in terms of reducing $\mathrm{CO}_{2}$. In particular, in local server rooms of cities in Poland, selected solutions for optimization of energy consumption such as those functioning in professional data centers can be applied. Savings in electricity consumption can be achieved by, e.g., widespread use of virtualization and elimination/disconnection of redundant servers, network and peripheral devices and services, purchase of new and often energy-efficient servers and network and peripheral devices (with energy certificates) and their proper configuration (e.g., setting ECO mode), setting up ECO mode in the server room, etc., setting the work in the ECO mode), ensuring proper cooling of the server room (e.g., setting moderate temperature of the air conditioner, sealing doors and windows, heat-insulating layers on the walls and ceiling, automatic closing doors, using the system controlling cooling in the server room, etc.) and lighting the server room (e.g., with LED diodes). An important measure that can reduce electricity consumption is to audit the existing electrical system (e.g., inspect the quality of wiring, check the efficiency of electrical equipment) and make appropriate modernization changes. Individual cities can also obtain energy to power IT infrastructure from photovoltaic panels and generally adopt the principle of seeking energy savings in every activity, every process and every area of ICT technology and reinforce the awareness of IT staff and the habits of other employees that reducing electricity consumption and $\mathrm{CO}_{2}$ reduction is a common goal.

The level of $\mathrm{CO}_{2}$ emissions can be significantly reduced as a result of reducing the role and modernization of existing and widespread coal-fired power plants in Poland to the widespread acquisition of energy from RES (renewable energy sources) by power plants. Then, cities in Poland can look for and sign contracts with those electricity suppliers that obtain energy from RES. Moreover, cities can sign agreements with suppliers of products and services on the necessity of their compliance with environmental regulations within the framework of their activity. Optimization of the IT equipment (and consumables) recycling program implemented in a given city may also have some impact on $\mathrm{CO}_{2}$ emissions. The main limitation of this research is not including the geographical localizations of data 
centers used by cloud computing providers, such as Amazon, Google, and Microsoft. They can be located, for example, in China and south Asia where carbon best practices may not be followed.

There are also similar studies related to carbon footprint reduction. Very interesting is an energy management in mobile devices. Ref. [6], for example, presents the clustering scheme that allows self-configuration and adaptation of the mobile device network, which allow to sustainable distributing energy consumption among clusters. Ref. [7], in turn, presents a study related to energy consumption behavior of representative data mining algorithms running on mobile devices. Additionally, the life cycle assessment of mobile devices is analyzed [8].

Further research works may concern, for example, reducing the city's carbon footprint using artificial intelligence methods and analyzing the environmental life-cycle costs of products and services offered by cities using IT infrastructure.

Author Contributions: Conceptualization T.T., D.D. and M.H.; methodology T.T., D.D. and M.H.; writing-original draft preparation T.T., D.D. and M.H. (Introduction-M.H., Materials and Methods and Results-T.T. and D.D., Conclusions-M.H.). All authors have read and agreed to the published version of the manuscript.

Funding: This study is supported by the project financed by the Ministry of Science and Higher Education in Poland under the program "Regional Initiative of Excellence" 2019-2022, project number 015/RID/2018/19, total funding amount 10,721,040.00 PLN.

Institutional Review Board Statement: Not applicable.

Informed Consent Statement: Not applicable.

Data Availability Statement: Not applicable.

Conflicts of Interest: The authors declare no conflict of interest.

\section{References}

1. Bytniewski, A.; Matouk, K.; Rot, A.; Hernes, M.; Kozina, A. Towards Industry 4.0: Functional and Technological Basis for ERP 4.0 Systems. In Towards Industry 4.0-Current Challenges in Information Systems; Studies in Computational, Intelligence; Hernes, M., Rot, A., Jelonek, D., Eds.; Springer: Cham, Swizterland, 2020; Volume 887.

2. Sunyaev, A. Cloud computing. In Internet Computing; Springer: Cham, Swizterland, 2020; pp. 95-236.

3. Camero, A.; Alba, E. Smart City and information technology: A review. Cities 2019, 93, 84-94. [CrossRef]

4. Ahad, M.A.; Paiva, S.; Tripathi, G.; Feroz, N. Enabling technologies and sustainable smart cities. Sustain. Cities Soc. 2020, 61, 102301. [CrossRef]

5. Khosravi, A.; Buyya, R. Energy and carbon footprint-aware management of geo-distributed cloud data centers: A taxonomy, state of the art, and future directions. In Sustainable Development: Concepts, Methodologies, Tools and Applications; IGI Global: Hershey, PA, USA, 2018; pp. 1456-1475.

6. Comito, C.; Talia, D.; Trunfio, P. An Energy-Aware Clustering Scheme for Mobile Applications. In Proceedings of the 2011 IEEE 11th International Conference on Computer and Information Technology, Paphos, Cyprus, 31 August-2 September 2011; pp. 15-22.

7. Comito, C.; Talia, D. Energy consumption of data mining algorithms on mobile phones: Evaluation and prediction. Pervasive Mob. Comput. 2017, 42, 248-264. [CrossRef]

8. Song, X.; Li, B.; Lv, B.; Chen, Q.; Bai, J. Life cycle energy use and carbon footprint of waste mobile phone treatment system. China Environ. Sci. 2017, 37, 2393-2400.

9. Xu, M.; Buyya, R. Managing renewable energy and carbon footprint in multi-cloud computing environments. J. Parallel Distrib. Comput. 2019, 135, 191-202. [CrossRef]

10. Singh, A.; Kumari, S.; Malekpoor, H.; Mishra, N. Big data cloud computing framework for low carbon supplier selection in the beef supply chain. J. Clean. Prod. 2018, 202, 139-149. [CrossRef]

11. Mehta, J.A.; Nanavati, P.K.; Mehta, V.K. A Survey On Green Cloud Computing. Int. J. Eng. Appl. Sci. Technol. 2021, 6, 425-429.

12. Dogo, E.M.; Salami, A.F.; Aigbavboa, C.O.; Nkonyana, T. Taking Cloud Computing to the Extreme Edge: A Review of Mist Computing for Smart Cities and Industry 4.0 in Africa. Edge Comput. 2018, 107-132. [CrossRef]

13. Mell, P.; Grance, T. The NIST Definition of Cloud Computing; National Institute of Standards \& Technology: Gaithersburg, MA, USA, 2011; p. 2.

14. Haag, S.; Cummings, M. Management Information Systems for the Information Age; McGraw-Hill/Irwin: New York, NY, USA, 2005; p. 205 
15. Marston, S.; Li, Z.; Bandyopadhyay, S.; Ghalsasi, A. Cloud Computing-The Business Perspective. Decis. Support Syst. 2011, 51, 176-189. [CrossRef]

16. Dziembek, D. Cloud Computing-Charakterystyka i Obszary Zastosowań w Przedsiębiorstwach; PTZP: Opole, Poland, 2016; pp. 725-739.

17. Gill, S.S.; Buyya, R. A Taxonomy and Future Directions for Sustainable Cloud Computing: 360 Degree View. ACM Comput. Surv. 2019, 51, 1-33. [CrossRef]

18. Mateos, A.; Rosenberg, J. Chmura Obliczeniowa. Rozwiazania dla Biznesu; Helion: Gliwice, Poland, 2011.

19. Catteddu, D. Cloud Computing: Benefits, Risks and Recommendations for Information Security. In Iberic Web Application Security Conference; Springer: Berlin/Heidelberg, Germany, 2010; p. 17.

20. Watson, A.; Musova, Z.; Machova, V.; Rowland, Z. Internet of things-enabled smart cities: Big data-driven decision-making processes in the knowledge-based urban economy. Geopolit. Hist. Int. Relat. 2020, 12, 94-100.

21. Mishra, K.N.; Chakraborty, C. A novel approach toward enhancing the quality of life in smart cities using clouds and IoT-based tech-nologies. In Digital Twin Technologies and Smart Cities; Springer: Cham, Switzerland, 2020; pp. 19-35.

22. Ercin, E.; Hoekstra, A.Y. Carbon and water footprints: Concepts, methodologies and policy responses. In World Water Assesment Programme; United Nations Educational, Scientific and Cultural Organization: Paris, France, 2012.

23. Radu, A.L.; Scrieciu, M.A.; Caracota, D.M. Carbon Footprint Analysis: Towards a Projects Evaluation Model for Promoting Sustainable Development. Procedia Econ. Finance 2013, 6, 353-363. [CrossRef]

24. Wiedmann, T.; Minx, J. A Definition of 'Carbon Footprint'. In Ecological Economics Research Trends; Chapter, 1, Pertsova, C.C., Eds.; Nova Science Publishers: Hauppauge, NY, USA, 2008; pp. 1-11.

25. Serweta, W.; Gajewski, R.; Olszewski, P.; Zapatero, A.; Ławińska, K. Analiza Wartości Śladu Wẹglowego dla Grupy Obuwia Dziecięcego; Instytutu Gospodarki Surowcami Mineralnymi i Energią PAN: Kraków, Poland, 2018; p. 107.

26. Kulczycka, J.; Wernicka, M. Zarządzanie śladem węglowym w przedsiębiorstwach sektora energetycznego w Polsce-Bariery i korzyści. Polityka Energetyczna-Energy Policy J. 2015, 18, 61-72.

27. ISO 14067:2018, Greenhouse Gases-Carbon Footprint of Products-Requirements and Guidelines for Quantification. Available online: https: / / www.iso.org/standard/71206.html (accessed on 1 June 2021).

28. Greenpeace USA, Clicking Clean: Who is Winning the Race to Build A Green Internet? Available online: http:/ / www.clickclean. $\mathrm{org} / \mathrm{uk} / \mathrm{en} /$ (accessed on 1 June 2021).

29. Techopedia, Carbon Footprint. Available online: https://www.techopedia.com/definition/2097/carbon-footprint (accessed on 1 June 2021).

30. Badanie Ericsson: Jaki Ślad Węglowy Zostawiają Urządzenia Cyfrowe. Available online: https://infowire.pl/generic/release/49 5410/badanie-ericsson-jaki-slad-weglowy-zostawiaja-urzadzenia-cyfrowe (accessed on 1 June 2021).

31. Lean ICT: Towards Digital Sobriety. Available online: https://theshiftproject.org/wp-content/uploads/2019/03/Press-kit-LeanICT-TSP2019.pdf (accessed on 1 June 2021).

32. Overton, J. Fact Sheet I The Growth in Greenhouse Gas Emissions from Commercial Aviation; Environmental and Energy Study Institute: Washington, USA, 2019.

33. Rizk, S. What colour is the cloud? Available online: https:/ /www.eib.org/en/stories/digital-footprint (accessed on 1 June 2021).

34. Czy nowe Technologie Pomogą Zmniejszyć Nasz Ślad Węglowy? Available online: https:/ / capgeminipolska.prowly.com/1128 96-czy-nowe-technologie-pomoga-zmniejszyc-nasz-slad-weglowy (accessed on 1 June 2021).

35. Burnicki, C. Cloud Computing and Carbon Footprint, How Vendor Lock-in Can Harm a Company's Green Business Plan. Available online: https:/ / www.innoq.com/en/blog/cloud-computing-and-carbon-footprint (accessed on 1 June 2021).

36. Masanet, E.; Shehabi, A.; Ramakrishnan, L.; Liang, J.; Ma, X.; Walker, B.; Hendrix, V.; Mantha, P. The Energy Efficiency Potential of Cloud A Based Software: U.S. Case Study; Lawrence Berkeley National Laboratory: Berkeley, CA, USA, 2013.

37. The Green Behind the Cloud. Available online: https://www.accenture.com/us-en/insights/strategy/green-behind-cloud (accessed on 1 June 2021).

38. Shankar, R. Can Cloud Computing Reduce Carbon Emissions? Available online: https://isg-one.de/articles/can-cloudcomputing-reduce-carbon-emissions (accessed on 1 June 2021).

39. Hölzle, U. Data Centers Are More Energy Efficient than Ever. Available online: https://blog.google/outreach-initiatives/ sustainability / data-centers-energy-efficient (accessed on 1 September 2021).

40. Earth5r, Cloud Computing: Environmental Impacts and Sustainability, Technology Going Green. Available online: https: / / earth5r.org/environmental-benefits-cloud-computing (accessed on 1 June 2021).

41. Carbon Footprint. Available online: https://sustainability.aboutamazon.com/environment/sustainable-operations/carbonfootprint (accessed on 1 September 2021).

42. Microsoft Set to Reboot Its Carbon Footprint. Available online: https://www.borntoengineer.com/microsoft-set-to-reboot-itscarbon-footprint (accessed on 1 September 2021).

43. Google Says Its Carbon Footprint Is Now Zero. Available online: https:/ /www.bbc.com/news/technology-54141899 (accessed on 1 September 2021).

44. Amazon, Google, Microsoft: Here's Who Has the Greenest Cloud. Available online: https://www.wired.com/story/amazongoogle-microsoft-green-clouds-and-hyperscale-data-centers (accessed on 1 September 2021).

45. Standard Performance Evaluation Corporation. Available online: https://www.spec.org/spec/ (accessed on 1 June 2021). 
46. Dlaczego nie Warto Kupować Starego Serwera. Available online: https:/ / dataspace.pl/blog/dlaczego-nie-warto-kupowacstarego-serwera (accessed on 1 June 2021).

47. Wskaźniki Emisyjności $\mathrm{CO}_{2}, \mathrm{SO}_{2}, \mathrm{NO}_{x}, \mathrm{CO}$ i Pyłu Całkowitego dla Energii Elektrycznej. Available online: https://www.kobize. pl/uploads/materialy/materialy_do_pobrania/wskazniki_emisyjnosci/Wskazniki_emisyjnosci_grudzien_2020.pdf (accessed on 16 June 2021).

48. Willerval, C. Measure the Server-Side Impact of Your Application with PowerAPI. Available online: https://blog.theodo.com/20 20/05/greenit-measure-server-energy-consumption-powerapi (accessed on 16 June 2021).

49. RenSMART Calculators; Wet-Wired.com Ltd. 2020. Available online: https://www.rensmart.com/Calculators/KWH-to-CO2 (accessed on 19 June 2020). 